\title{
Sociología
}

Jurca, R. L., \& Ianni, A. M. Z. (2019). Social policies, neoliberalism and individualization in the periphery of São Paulo, Revista de Sociología, 34(2), 34-49. doi: 10.5354/0719-529X.2019.54608

\section{Social policies, neoliberalism and individualization in the periphery of São Paulo}

\author{
[Políticas sociales, neoliberalismo e individualización en la periferia de \\ São Paulo]
}

\author{
Ricardo de Lima Jurca (D) \& Aurea Maira Zöllner Ianni (D) \\ Universidad de São Paulo
}

\begin{abstract}
The present article explores the expansion of the public and private health segment in response to the needs of the population of a peripheral sector of the South Zone of São Paulo, Brazil. Management of the sector is led from the margins of the capitalist peripheral State in the context of the current crisis of democracy which is driving a gradual individualization of social policies. As such, this management is both social and structural in nature. In addition to those users of the system who were interviewed, participants in the research included social leaders, Basic Health Unit (UBS) professionals, and agents of the Family Health Strategy (ESF) primary healthcare program. We focus on the continuities and discontinuities of public policies and highlight the important role that strategies of containment and reproduction of poverty have played in the process of legitimizing the democratic regime in Brazil.
\end{abstract}

Keywords: democracy, public health, neoliberalism, periphery, individualization.

\section{Resumen}

Este artículo pretende comprender la expansión del segmento de salud pública y privada como respuesta a las necesidades de la población de un territorio periférico de la zona sur de la ciudad de São Paulo. Esta gestión se basa en los márgenes del estado periférico capitalista, ya que considera que la crisis de la democracia es una acentuación de los elementos genéricos que operan actualmente en un contexto de individualización de las políticas sociales y, por lo tanto, tiene un carácter social y estructural. Además de los usuarios entrevistados, participaron en la investigación, líderes sociales, profesionales de la Unidad Básica de Salud (UBS) y agentes del programa de atención primaria de salud, Estrategia de Salud Familiar (ESF). Buscamos privilegiar las continuidades/discontinuidades de las políticas públicas y resaltar la importancia que han jugado las estrategias de contención/reproducción de la pobreza en el proceso de legitimación del régimen democrático en el país.

Palabras clave: democracia, salud pública, neoliberalismo, periferia, individualización.

Contacto / Contact: La correspondencia debe ser enviada a / Correspondence should be adressed to: Ricardo de Lima Jurca, email: rljurca@usp.br

Financiamiento / Funding: Coordenação de Aperfeiçoamento de Pessoal de Nível Superior (CAPES) N $^{\circ}$ 2015/1560056 and Fundação de Amparo à Pesquisa do Estado de São Paulo (FASESP) Nº 2015/16218-0. 


\section{INTRODUCTION}

The specific objectives of this article are based on the assumption that, in the wake of the crisis of lulism (Singer, 2018), from 2015 onwards the rise of a strong counter-reformism, characterized in general terms, cuts in the volume of public expenditures and, consequently, in the activity. The counter-reformist rise further strengthens the market position as the most important mechanism in the distribution of life opportunities, of market justice (Streeck, 2018), and thus proceeds and concludes the neoliberal program of symbolic erosion of social rights. At the same time, there was an escalation of antidemocratic exceptionalism. Such a process, which went through the impeachment of Dilma Rousseff in 2016, without proof of a crime of responsibility, and the transitional government of Michel Temer, culminated in the electoral victory of an extreme right-wing candidate, Jair Bolsonaro, in 2018.

Particularly in this work it is essential to understand how people build their institutional ties in everyday life through different government actions and projects, social organizations and institutions and the marketthus maintains a close link to the issue of access to health services. Therefore, we seek to deepen the empirical research on the new social health policy, to establish links between the movements that expanded health management in the south zone of the city of São Paulo with the private health segment.

The health policies -as social policies of universalization that are under development- still have a corporatist aspect. From this angle, it is possible to speak of various types of neoliberalism. Such a conception would allow us to think about the ambivalence produced by the role of the market and its dynamics through social policies (Oliveira, 2013, 2018; Paoli, 2007). According to Dardot and Laval (2016), neoliberalism is the reason for contemporary capitalism that determines a new way of governing men in accordance with the universal principle of competition, implying a reduction of social rights, including health policy, within which intensification of commodification mechanisms present in the context of central and peripheral capitalist countries, such as Brazil.

In this line, the relationship between the question of health policies and the history of capitalism is an essential instrument to reflect on the limitations that social policies of universalization have been suffering precisely in this period, in which neoliberal thinking is present in a hegemonic way including in the scope of access to health services. Its effects, among others, have been hampering the budgets of the public fund, which compromises the maintenance of the rights associated with the social state and the realization of the new social rights introduced in those countries of late capitalism, such as Brazil.

Thus, one can consider how the action via public policies could acquire the logic of the capital movement and must be resumed when discussing the role of social programs in the contemporary world. It is also possible to reflect 
with the aim of illuminating a critical debate about the institutional pattern adopted by the field of collective health throughout the years of the implementation of the unified health system (SUS for its abbreviation in Portuguese), Economic thinking and its relationship with health: the preponderance of neoliberal vision.

The health care intermediation scheme practiced by the private health segment, operating in the Brazilian health system, will be conceived in the framework of the debate of the new Brazilian social policies, dedicated to the analysis of actions and grammars that are triggered between social health programs, neighborhood associations and social health organizations (Georges \& Santos, 2016; Rizek, 2013, 2016).

The social organizations are legal entities of private law, non-profit, whose activities are directed to health, meeting the requirements established in this law. Thus, the choice to focus the analysis on the social health organization and the family health strategy program is linked to the fact that this partnership is very centrally constituted by the nexus of privatization of the public space, following and adapting the significant political transformations, as well as becoming part of spaces that are classified as socially vulnerable, in a very capillary way.

The constitutional registration of SUS and its implementation over the last three decades have not been able to contain the deepening of the neoliberal logic in the health sector. The SUS is, according to the law, a set of health actions and services, provided by public, federal, state and municipal bodies and institutions, direct and indirect administration and foundations maintained by the public power. Based on articles 196 and 198 of the federal constitution of 1988, Brazil guaranteed its population universal, integral, equal and free access to health through a single decentralized system.

The studies in the field of collective health on democracy and sanitary reform (Ianni, Mendes, Marques, Coelho, \& Jurca, 2017), in the context of the post-constituent period in Brazil, resorted to the critical perspective inspired by the analysis the simple introduction of the notion of class interests (Mendes, Ianni, Marques, Ferreira, \& Silva 2017).

This is explicit when Teixeira $(1989,1992)$ argues in this perspective, by placing citizenship as a fundamental category in its analysis of the formulation of a theory for sanitary reform, especially in a country on the periphery of capitalism, such as Brazil, Teixeira seeks to understand the issue of citizenship not only as a space of consensus between classes, but mainly as a space for strengthening of the struggle and for the counter-hegemony of the subaltern classes.

Thus, the process of policy formulation (with emphasis on health policy) must consider the particular presence of the emerging social policy in a context of backward industrialization, which was markedly different from that of liberal democracy. Firstly, there is a consensus about the need for protection that permeates the whole of society, and secondly, the state is the mentor of the project and not the workers.

The results of this process allow the structuring of a system of social protection that is not guided by the principles of universalization, but rather 
by the "differentiation of the categories of workers in relation to the list of benefits to which they have access" (Teixeira, 1989, p. 23). The lack of participation of the organized workers in the debate of this project ended up being a serious problem the movement for the sanitary reform had to face at the beginning of its formation.

Programs, management and access to health services

The performance of social programs of the health program such as the family health strategy (ESF for its abbreviation in Portuguese), is fundamental in the production of postconstitutional social policies, as an example of the progress of the neoliberal process on the margins of the primary healthcare. The differentiation of access for the users of the public health services in the periphery of São Paulo demonstrates the intertwining of the public and private dimensions of the historicalstructural conception for the health area as a new paradigm in the knowledge of the relationship between health care and society.in the quotidian access to health services

The challenges to implement social policies, in this case, health, are presenting answers that are dissociated from the principles defined by legislation. The ESF was the proposal to change the model and it is not a basic package of healthcare provision for the poor (Cohn, Nakamura, \& Gutierres, 2009). However, this experience, once implanted in São Paulo, led the public sector to provide services to the private market rationality, cost/effectiveness, for example, were prevailing to the detriment of social, public rationality.

The ESF was integrated into the unified health system as an initiative that promotes the prevention and identification of diseases, as well as sanitary education, as opposed to curative actions centered on hospitals. The ESF has been developed by multidisciplinary teams that operate in the districts of several municipalities Brazilian from a basic health unit (UBS), whose mission is to provide locally basic health guidelines locally and, if necessary, to refer patients to specialized agencies (Ministério da Saúde, 2002).

In Heliópolis, the practices of the Paulista Association for Medical Development (SPDM for its abbreviation in Portuguese), an organization associated with the federal university of São Paulo which assumed the management of the Sacomã's basic units of health (UBS for its abbreviation in Portuguese), the local basic health unit and community health agents (ACS for its abbreviation in Portuguese). Both are now hired to fulfill fixed-term contracts, leading to high employee turnover, and thus the informalities of the state system have been deepened.

Basic units of health or UBS is a designation adopted since 2007 in Brazil through the program for growth acceleration, with such units perform the same functions of the former health posts being such the name gradually replaced by basic health unit planning. And the work of managing the flows carried out by ACSs requires them to assign a level of priority to the demands, 
adapting to the availability of medical services. Each team is composed of a doctor, a nurse, a nursing assistant and five agents of the community health systems, with the group responsible for per thousand families in a given area. The mission of an ACS is to approximately 200 households at home. In most cases, the ACSs only elementary school to participate in a selection of for the position (Ministério da Saúde, 2001).

The activities of community health agents -characterized by social capillarity in the local community, use of neighborhood mutualaid networks, knowledge of the territory etc.- have been incorporated to the healthcare portfolio of the contracted company, according to a rationale of service efficiency and minimal cost. This allows the public policy of primary health care to be implemented with minimal social conflict, outsourcing all responsibility to individuals (Georges \& Santos, 2016).

The way agents communicate with users is demonstrative of the privatization and growing segmentation of the health system. As residents of the community, the agents have the function, which consists in connecting to public services. Therefore, face-to-face interaction at the hospital reception desk is giving way to increasingly singularized and fragmented forms for the provision of public services, and these forms increasingly regulate the relationships between users, state and market. The individualization of social policies, in this sense, has been accompanied by somewhat of a plot twist, with consequences for the distribution of social benefits (in this case, access to healthcare).
One of the facets of the peripheral individual's current historical condition (Rizek, 2016) is the fact that this individual has to live under the umbrella of thousand modalities of distinct services within the same health system. The confusion and interpenetration of the public and private spheres, in the case of Heliópolis, can be seen in the particular characteristics of both the UBS units and the outsourcing company, as well as in the relationships of the community health agents with the population.

According to Léa Lima (2010), the implementation of these social policies often includes the creation of collective deliberation instances aimed at addressing particular cases and individuals. The allocation of rights and services in the social policy domain is increasingly moving away from a universalistic and automatic, no-questions-asked model, towards complex negotiation processes within social programs, whose function is to allow or disallow social rights through the assessment of individual cases.

The individualized social benefits represent a new population management tool, besides standardized knowledge and classification tools, which Castel (1981) denunciated as negative effects at the end of the 1970s decade. Or still the idea of poverty as a business niche, Rizek (2010, 2013, 2016) exploited in various texts.

These elements, which are presented in a summarized way, point to a significant increase in a margin of action destined to private healthcare, as operator of an outsourcing social health program, in which it assumes management and staff recruitment, the 
responsibility for financial management. Indeed it endorses besides the complete management of this service, the role of a financial operator, having in its portfolio of power-delegated missions the raising, allocation, and management of the monies (from the private sector, large companies and the public sector), by acting in a range of diversified partnerships. By carrying out these activities, medical care comes to operate business niche in the private sector (laboratories, clinics, and out-of-pocket polyclinics). Thus, a performance, permeated by the public-private hybrid partnerships, in which it becomes increasingly difficult to discern the state's performance and sovereignty is established, generalizing what has been called commodity policy (Misse, 1997). In the control over the financial flows, as well as over political decisions and over rights, in the context of the implementation of these social policies the prospect of the claim on some collective right, of a universal coinage (Lautier, 2014) obscures and vanishes.

Ultimately, the issue deals less with the primacy of the of the social state over society and more with the destabilization of protective social networks which consolidates itself as a coproducing system for the market. When we consider the distinct facets of the state as a producer, provider and regulator and the way in which hybrid system of social protection is being created, it becomes evident that a scale of rights, semi-rights or almost-rights is being established (Cohn, 1996, 2009)

\section{METHOD}

This work is based on the results of the study Individualização social, assistência médica privada e consumo na periferia de São Paulo (Social individualization, private medical care and consumption in the periphery of São Paulo). The research was conducted by means of empirical research field (Marcus, 2011) with the mapping of the public and private interfaces of healthcare in everyday life, taking as an anchor health policy as well as the networks that are established from their equipment and from public and private management practices.

Given that the contacts in the management of the primary healthcare programs were the starting point of this research some immersions of periodic field work were programmed in Heliopolis: i) between January and June 2016 and; ii) between August 2016 and January 2017 (12 months in the territory).

The strategies mobilized in field trips, following the routines and connections of the basic health unit Sacomã with the SPDM social organization, were based on the following set of empirical and analytical practices: (i) resumption of the incursions into the territories, to which we had access in 2015, conducting conversations with interlocutors connected to the circuits of the family health strategy program, with whom we 
already have a relationship of trust and research, recording the findings in field journals; (ii) systematic retrieval of each piece of field diary, interview or situation experienced with the actors enrolled in the daily life of UBS; (iii) analytical reconstitution of the routes the users go through (four interviews), health agents (two interviews), professionals of UBS (one interview) and neighborhood associations such as UNAS (Union of Nuclei of Social Associations of Heliópolis) (three interviews), in the different directions they took along the social network connections in the circuit.

Therefore, the focus of the field research remained in the institutional spaces that made up the entanglement in which the relationship of partnership between social organization and average private assistance and the connections with clinics, polyclinics, and out-of-pocket laboratories are inserted. But the research also aimed at exploring dimensions and relationships as well as networks that are established from this object.

The bibliographical and documentary research had as starting point the theoretical bibliography which is the basis of the approach that is proposed here, articulated with the ethnography of the state (Das \& Poole, 2004), with the new Brazilian social policies (Georges \& Santos, 2016; Rizek, 2016).

A part of the extraction of our field experience and of the interviews we conducted in that period came from the preliminary screening of the material we produced and accessed in the field field diaries and interview transcripts; through the intensive analysis and definition of the central dimensions in the script of interviews, relevant to the research; and followed in the direction of the elaboration of the social spheres (in this case users, ACS, UBS, associations), starting from the detailed examination of the selected material, and its ordering by content and pattern based on the activities inserted in the context of the research to portray the relations which, in the local dynamics, are operative in the definition of distinctions and conformations of practices. This procedure opened the possibility to resort to the theory and relevant analyzes of the fields with which this work dialogued in order to experience the relation of the social groups in an inductive way from the field research with the actors mobilized in the social network we studied.

Except for the health professionals of UBS, the inclusion of a respondent takes into consideration, in addition to their profession, the neighborhood of residence (Heliópolis), and the trajectory in the public health system of the same interviewees. In this sense, the relational factors explored in the interviews are essential, since they expressed the centrality of the different affiliations of the actors involved in the management of the UBS and ESF, and their socioeconomic profile, composed of a segment that lives in favelas - slums.

More specifically, the study allows us to think about the users in the margins of the social network, whose access to health services defines the fluctuating limits between the market and the state, and how these individuals are located in the public and private interfaces of social health management. It is a matter of showing, in 
a wide angle, as in the daily experience of the population, health professionals and social leaders, public policies and institutions are crossed by the popular affirmation (Bidet, 2018) of the users of the services and social programs. In addition to mediations in the structures of the market and the state, the political organization must consider the immediate politics that is expressed through popular affirmation practices (Bidet, 2018).

It is worth noting that the implementation of social policies favored the neoliberal historical and contradictory continuity, be it properly in the space of labor relations, or in the public policy plan directed at the lower and excluded classes. Recently, with the social, political and economic crisis that has hit Brazil, especially since 2015, we have seen a rupture of the sustained equilibrium in socially negotiated mediations, which are characteristics of the recent past. This discontinuity needs to be investigated, understood and recorded in sociological terms.

Some of the issues we approach in this regard revolve around how: the reconfigurations of public policies in the current post-Lula context tend to strengthen or weaken the contestatory capacity of the social groups analyzed, particularly in cases associated with claims in the health sectors.

The interview script contained questions about the interviewees' lives and careers, as well as four types of inquiries:
- How they perceived the results of recent changes in the favela of Heliópolis, to capture the meanings of the residents' daily experiences.

- Their relationship with other community agents, to know more about the relationships between local associations, government and market, in the provision of healthcare.

- What material and immaterial resources were available to them, to know more about economic or informational resources provided by their social inter-relations network, to grant access to public or private health services.

- How they related to the expansion of private enterprises in the favela, including healthcare providers, to get a sense of the qualifications, definitions and moral values attributed to clinics, polyclinics and health laboratories in recent years.

All names quoted are fictitious. An informed consent form clarified, using a clear and objective language, through which subjects were informed about the objectives of the study, data collection, procedures, possible constraints or benefits guaranteeing, confidentiality, and respecting the desire to participate. The informed consent also contains authorization volunteers for the presentation of the results found in scientific events. The anonymity and privacy of the participants were sheltered. After signed, a copy of the document stayed with the research subject and another stayed with the researcher responsible for it. 


\section{RESULTADOS}

As we previously observed, the ethnographic component of the project was focused on the study of the different social dimensions located in the social networks of public policy agents, users, and social leaders. In order to develop accurate and contextualized understandings of the internal life of social groups, we used participant observation techniques and interviews in order to explore the selected cases. Examining the existing relationship between the structure of relationships of individuals, the dimensions of changes in material and immaterial relationships, relationships with social associations and the expansion of healthcare companies in the favela, in this article we sought to analyze the insertion of private medical care in the social networks of the inhabitants of the favela of Heliópolis. Thus, the first phase of the research revealed that the social networks of the inhabitants of the favela of Heliópolis were dense and centralized. They were very local networks, with sociability variability, but mainly based on neighborhood and family relationships.

Beck (2002) proposes the term post-family to describe this process of transformation of privacy related to individualization, and Martin (2007) prefers the term family-welfare to show the importance of its intervention in relation to state welfare.

In a second phase, from the analysis of the practices and discourses of a way of insertion of the public system users in private healthcare, through the four dimensions that are highlighted in the methods, it was possible to reveal the nature of the relationship between individuals and the changes in social relationships.

The dimension of the recent material changes in social relationships in Heliopolis.

Adão, speaks of the world economic circuit in which Heliopolis is inserted:

"This is an issue that because of the Brazilian and world crisis, it is difficult for people to have money like this for ... but that view that the favela, community, people do not have money, that's the past. If you are walking around there you will see the situation it is, the number of cars and the quality of the houses is, let's just say, middle class" (Interview on June, 15 2016).

"Heliopolis is a center; it is a mine. For whom that has the money to invest here it will work out. Everything that opened here worked out, does not close; there's no reason why. There are lots of people here. There are more than two hundred thousand people who live inside and are willing to spend money. So it's a place that attracts attention. On the Estrada das Lágrimas -Road of Tears- all the houses became shops. On this side [neighborhood Sacomã] there was no shop five years ago. There was nothing there. So you see that now there are these brand stores, Marisa, Casas Bahia, Magazine Luiza, bank. So it's on the rise", says Adão" (Interview on June, 15 2016). 
It is through these types of interactions that their everyday life, consumption practices, forms of sociability and forms of expression are reconfigured. The various social achievements of Heliopolis seem to consider it a possible model favela, however, behind this apparent development, essential social issues are still present in the same space.

The dimension of the relationship with the social associations.

Social ascension is polysemic, plural in its sources and usually constant in the social movements of the periphery of São Paulo, but the social rise of the last decades gives rise to an atmosphere of common concern to many individuals located in different social strata. According to Araujo and Martuccelli (2011), to delimit this position it is worth differentiating it by the notion of positional inconsistency and social mobility.

As to social associations, we followed the work of young social leaders Ninine and Carolina, who coordinate the project Facebook in the Community, of the Association UNAS.

As Carolina, who observes the recent changes in social relations in Heliópolis, says:

"What I call individualized has to do with struggles, you know. People think I have a guaranteed job, that I do not need to worry about my neighbor who is unemployed or about the labor reforms. We created a social program, right? We participated in programs as teenagers. I have participated in such programs since the age of ten" (Interview on August 6 2016).

On this social project, that develops entrepreneurship in Heliopolis, the leader Ninine states:

"We serve the retail businesses, but only the ones within Heliópolis. Well, the goal of the program is to make an entrepreneurial neighborhood out of Heliópolis, right? And then we expanded the project, because we saw that there was a lot of demand out there. But this service of ours is limited to the shopkeepers of Heliópolis" (Interview on June 5, 2016).

Ninine described the development of a healthcare-related mobile app for the community:

"The idea of the laboratory here in Heliópolis, since 2015. This was the first step. [After that] we came up with the idea to offer an application [development] course to the community. [To offer] a programming course. To call the young people who were interested and even the entrepreneurs, in order to create an application to use here. Then at this stage of the program, the idea was to form groups in order to have an idea about an application that would benefit the community, which would somehow make the community grow. They thought of the health issue and said on the day of the presentation that it was very important to them because today it's chaotic here, you do not know where to find a [medical] specialist, you do not know where you can find medicine, you do not know at what time [the doctor] is available. You 
cannot schedule [consultations] properly. And then they said: let us create an application for this. And they [were very interested], they worked on it, because they wanted this app to be developed. So much that it is now on Google Play" (Interview on January 26, 2016).

The dimension of material and immaterial relations for access to health services.

"A neighbor was complaining about the delay in consultation here. I said it seems that Dr. Consul is not very expensive, sixty [R $\$$ 60]. Then she went and it looked like she was already having the mammogram. Then she paid one hundred Reais $[R \$ 100]$ to have it done. Then she went there to get take the exam result and took it to the doctor, says Ana" (Interview on April, 22, 2016).

She talks about the new access alternatives when we ask about the popular medical clinics in Heliópolis:

"I used, this, I used it once, and so I know people like that, those particular ones you're talking about. Helped a lot, it helped a lot, because even though we are lower class, the poorer, it takes you a long time to wait for a specialist. So you make a little sacrifice and use it...they accept credit card installment payments In fact, I think it is increasing because there is already a new one near the avenue" (Interview on April, 22, 2016).

The agents and professional UBS have the function to connect the users with the public services, residing in the community where they work. The information resources used in the network of social ties for access to public or private health networks had community health agents as the main informants of the network.

ACS Maria commented on a price assessment she did for a patient of the local public health system, who needed an ultrasonography:

"I did the assessment because I have the contacts ... I called and found [exams ranging in price] from $R \$ 100$ to $R \$ 78$, in Dr. Consulta private health clinic for low-income users]" (Interview on March 10, 2016).

The ACS named the private laboratories she assessed: Lavoisier, Dr. Consulta and Ghuelfond Diagnósticos. Another patient of hers was able to find consultation prices of $\mathrm{R} \$ 80$ at Hospital Ipiranga, and $R \$ 30$ in the nearby municipality of São Caetano.

Jeane, an agent of the health family, reports on her budget for medical examinations in private medical clinics to continue treatment in the public system. The ACS believes:

"That private clinics for low-income users end up helping the local health unit [UBS]. It is common to have patients waiting for an appointment [in the public healthcare system] with an examination result from Dr. Consulta [already in their possession]. Low-cost clinics allow the treatment to be continued at the basic health unit. This is why the health unit [usually] schedules the appointment to a very distant date, or sometimes it makes an appointment and if the examination result is not ready you have to reschedule, and then it takes even longer" (Interview on June 22, 2016). 
The dimension of the expansion of the healthcare market in the favela.

Cleide, a community leader, comments on lowcost clinics in the favela:

"In the community, people are aging; they are retiring, so they get their pension every month,. right on time. They will not pay rent because they have already been residents for a long time. So what they had to spend to build their little house, they spent building, working, and now they are retired. I mean if it is one retiree, it is one pension, but if it is a couple there are two pensions that are in the account on the right day. And since he gets his pension every month, what will he do, take care of his health. If he has this place near his residence [clinic] so that he does not even need to take a bus, he [retired] goes alone. So it's very good for him. For the group that comes and runs these clinics, it's good for them. The only negative point is that it takes away the state's responsibility for doing what was their obligation" (Interview on March 2, 2016).

In the outskirts of São Paulo, it is quite common to see special discounts available to retirees, to pensioners, to those who are over the age of 60 , SUS patients, and the cost of medical examinations is split up to ten times, at the admission to popular medical clinics. On a quick field visit, it is possible to observe that in these territories, the potential clients of these clinics were elderly men and women who are over the age of 60 , providers of the families who used $U \$$ 203 from the continuous provision payment (CPP) [benefício da prestação continuada (BPC)], rural retirement and credit to create a social protection network (Jurca, 2018). At most banks encourage the masses to consume low coverage health plans. The federal government, for example, directly resorted to a public bank Caixa Econômica Federal (Federal Savings Bank), to offer highly segmented insurance in a strategy that is coupled with (Lavinas, 2017).

Another interviewee, Alaíde, told us that her last set of medical examinations was paid in six installments.

"I paid $\mathrm{R} \$ 238$ for the last installment. The doctor says 'I see a little spot here.' You get desperate. You pay the $\mathrm{R} \$ 90$ for the consultation, and then you get worried and pay more for the tests in order to see what the spot is. I went to another clinic and the doctor took that paranoia out of my head. I warned a friend who was warned by a doctor, also of Dr. Consulta, and who refused to undergo the examinations and to pay even more" (Interview on February 11, 2016).

Alaíde had a private health insurance plan, but nowadays she seeks alternatives outside the supplementary health care. She has been taking medicine for six years.

"I cannot stop because I suffer relapses" (Interview on February 11, 2016).

The blurring of the boundaries between public policy and private sphere could be observed both with respect to the characteristics of the respective areas of coverage, between the UBS and the private health services (pharmacies, clinics, diagnostic laboratories).

Fabiana, manager of UBS Sacomã, talks to us about the project Corujão da Saúde, the main 
health program in the current administration of São Paulo City Hall (2017-2020):

Everyone tells me that things have not changed much except the fact that the image review queue has decreased considerably. The specialties remain in the same queue. UBS Sacomã, at the Health Owl, is forwarding the users mainly to the Municipal Hospital Doctor Arthur Ribeiro de Saboya (public), German Hospital Oswaldo Cruz (private) and to the specialty center Arthur Gianotti in Ipiranga (public) and for some private clinics (Interview on Mars 30, 2017).

The Corujão will be implanted in hospitals of the public and philanthropic network, in addition to hospitals and private clinics agreed with the Municipal Health Department. The initiative aims to zero the queue of 485,300 exams within 90 days. The main types of establishments in this project are the private for-profit health sector are the complementary ones (general hospitals, specialized hospitals and diagnostic and therapy support units) and supplementary ones (isolated clinics, medical specialty centers, polyclinic).

Particularly in the south zone, the private health segments in a very complex way, seize the management of meanders of the financing processes, assemblages, and mechanisms that allow walking the operations of outsourcing of health in the state of São Paulo. "The number of establishments grew from $52.5 \%$ of the total in 2005 to $68.6 \%$ in 2013" (Viana, Miranda, \& Silva, 2015, p.14).

Kelen underwent all the imaging, transvaginal, pap smear and abdomen evaluation tests at a private clinic. She discovered that she had gallbladder stones, her health expenses increased, and she became indebted.

"The bad thing about the unit [UBS] is that it refers us to far away. My family's income is barely over R \$ 2000" (Interview on June 17, 2016).

She showed us her SUS registry sheet and said that without it she would not be able to obtain examinations at the private clinic for the prices offered to low-income users.

The choice of health as value can be observed in different ways. This process is well illustrated if we observe that the number of researches using functional magnetic resonance imaging to approach the subject-matters of human sciences increased dramatically in the $1990 \mathrm{~s}$, bringing to light objects such as guilt, shame, and religiosity, the results of which contribute to the transformation of ideas and practices in the moral, legal, social, political and other fields (Racine \& Illes, 2006).

\section{CONCLUSIONS}

The picture presented is still very preliminary and a more general understanding of the ongoing transformations towards the expansion of the private network that reduces the SUS to a kind of reinsurance of private operations in the last decades and it requires a more in-depth 
structural analysis. We restrict ourselves to recovering the main arguments presented in the text to take stock of the different social spheres social associations, social organizations, partner programs and users - that gravitate towards the right to health, demanding the efficiency of health services. That is, the field of public health policies becomes a privileged ground for the observation of the continuities/ruptures between the different political contexts from the perspective of the subaltern social classes.

In this hybrid scenario, which is not very clear, from an unprecedented junction between the recognition of social demand, social policies and the market, provoking a less evident transformation of social politics into business, understanding the performance of the for-profit private sector in the outskirts of São Paulo reveals a new field of research for society-statemarket relations. The plurality of public and private repertoires are present through crossings that eventually privatize, capture demand and moral regimes, reconfigured what constitutes one of the main characteristics of the forms of government of the 2000s (Georges \& Rizek, 2016).

The theme of the continuities/ruptures of the public policies of reproduction/containment of poverty as a privileged field where the tensions between social inequalities and democracy in the country are revealed could not fail to take over the health area. In order to look at the recent transformations and current trends in the transformation of health care in the country through the continuities/discontinuities that can be verified in the post-Lula context, a close look at the imminent cuts in the expenses of the state, especially those depend on public services for having low incomes. In general terms, cuts in the volume of public expenditures and thus in state activity seem to reinforce the market position in the context of health, strengthening private mechanisms to assist the poor, and at the same time overloading the unified health system.

On the one hand, we take as a research presupposition the change in the regime of visibility of these actors, that is, of a recent turning point in their trajectory in the postlullist era; and on the other, the generalization of a neoliberal rationality (Dardot \& Laval, 2016) that crosses the whole of production and reproduction activities, both dynamics being articulated among themselves. The transformations of the world of work, guided by the end of the social integration hypothesis through formal insertion in this universe and the generalization of the logic of selfentrepreneurship and of individual responsibility for the own employability, provide indications of how the continuities/discontinuities of the policies of containment/of poverty must advance along the Bolsonaro government. 


\section{REFERENCES}

Araujo, K., \& Martuccelli, D. (2011). La inconsistencia posicional: Un nuevo concepto sobre la estratificación social. Revista Cepal, 103(1), 165-178. doi: 10.18356/20764528-es

Beck, U. (2002). Zombie categories: Interview with Ulrick Beck. In U. Beck \& E. Beck-Gernsheim (Eds.), Individualization (pp. 202-213). London, UK: Sage.

Bidet, J. (2018). "Eux" et "nous"?: Une alternative au populisme de gauche. Paris, France: Editions Kimé.

Brazil. Const. Art. 196 and 198.

Castel, R. (1981). La gestion des risques. De l'anti-psychiatrie à l'après-psychanalyse. Paris, France: Ed. de Minuit.

Cohn, A. (1996). Desigualdade, desenvolvimento social e políticas sociais no Brasil. São Paulo, Brazil: Cedec.

Cohn, A. (2009). Saúde e desenvolvimento social. Saúde e Sociedade, 18(2), 41-47. doi: 10.1590/S0104-12902009000600006

Cohn, A., Nakamura, E., \& Gutierres, K. A. (2009). De como o PSF entrecruza as dimensões pública e privada da vida social. In A. Cohn (Ed.), Saúde da família e sus convergências e dissonâncias (pp. 141-167). Rio de Janeiro, Brazil: Beco do Azougue.

Dardot, P., \& Laval, C. (2016) A nova razão do mundo: Ensaio sobre a sociedade neoliberal. São Paulo, Brail: Boitempo.

Das, V., \& Poole, D. (2004). Anthropology in the margins of the state. Political and Legal Anthropology Review, 30(1), 140-144. doi: 10.1525/pol.2007.30.1.140

Georges, I., \& Rizek, C. (2016). Práticas e dispositivos: Escalas, territórios e atores. Contemporânea, 6(1), 51-73. doi: 10.4322/2316-1329.011

Georges, I., \& Santos, Y. G. (2016). As 'novas' políticas sociais brasileiras na saúde e na assistência: Produção local do serviço e relações de gênero. Belo Horizonte, Brazil: Fino Traço.

Ianni, A., Mendes, A., Marques, M., Coelho, D., \& Jurca, R. (2017). Pensamiento social en salud: Un análisis crítico de las obras clásicas del campo de la salud pública en Brasil. Revista Guillermo de Ockham, 15(2), 107-117. doi: 10.21500/22563202.3140

Jurca, R. L. (2018). Individualização social, assistência médica privada e consumo na periferia de São Paulo (Doctoral thesis, Universidade de São Paulo, São Paulo, Brazil). Retrieved from http://www.teses.usp.br/teses/disponiveis/6/ 6135/tde-04052018-113137/pt-br.php

Lautier, B. (2014). O governo moral dos pobres e a despolitização das políticas públicas na América Latina, Caderno $\mathrm{CRH}, 27(72)$, 463$477 . \quad$ doi: 10.1590/S010349792014000300002

Lavinas, L. (2017). The takeover of social policy by financialization: The brazilian paradox. New York, NY: Palgrave Macmillan.

Lima, L. (2010). L'expertise sur autrui comme nouveau mode de régulation de la protection sociale. Principes et dispositifs. Retrived from: https://halshs.archivesouvertes.fr/halshs-00699634/document

Marcus, G. E. (2011). Multi-sited ethnography: Five or six things I know about it now. In S. Coleman \& V. Hellermann (Eds.), Multisited ethnography: Problems and possibilities in the translocation of research methods (pp. 26-53). New York, NY: Routledge.

Martin, C. (2007). Le souci de l'autre dans une société d'individus. In S. Paugam (Ed.), Repenser la solidarité, l'apport des sciences sociales (pp. 219-238). Paris, France: PUF.

Mendes, A., Ianni, A., Marques, M., Ferreira, M., \& Silva, T. (2017). A contribuição do 
Jurca, R. L., \& Ianni, A. M. Z. (2019). Social policies, neoliberalism and individualization in the periphery of São Paulo, Revista de Sociología, 34(2), 34-49. doi: 10.5354/0719-529X.2019.54608

pensamento da saúde coletiva à economia política da saúde. Saúde Soc. São Paulo, 26(4), 841-860. doi: 10.1590/S010412902017170748

Ministério da Saúde. (2001). Programa Agentes Comunitários de Saúde. Brasília, Brazil: Ministério da Saúde.

Ministério da Saúde. (2002). As cartas de promoção da saúde. Brasília, Brazil: Ministério da Saúde, Secretaria de Políticas de Saúde.

Misse, M. (1997). As ligações perigosas: Mercado informal ilegal, narcotráfico e violência no Rio. Contemporaneidade e Educação, Salvador, 1(2), 93-116.

Oliveira, F. (2013). Crítica à razão dualistas: $O$ ornitorrinco. São Paulo, Brazil: Boitempo.

Oliveira, F. (2018). Brasil: Uma biografia não autorizada. São Paulo, Brazil: Boitempo.

Paoli, M. C. (2007). O mundo do indistinto: Sobre gestão, violência e política. In F. Oliveira \& C. S. Rizek (Eds.), A era da indeterminação (pp. 221-256). São Paulo, Brazil: Boitempo.

Racine, E., \& Illes, J. (2006). Neurothical responsibilities. The Candian Journal of Neurological Sciences, 33(3), 269-277. doi: 10.1017/S0317167100005138

Rizek, C. S. (2010). Verde amarelo azul e branco: $\mathrm{O}$ fetiche de uma mercadoria ou seu segredo. In F. Oliveira, R. Braga, \& C. S. Rizek (Eds.), Hegemonia às avessas (pp. 215-236). São Paulo, Brazil: Boitempo.

Rizek, C. S. (2013). Políticas sociais e políticas de cultura: Territórios e privatizações cruzadas. Revista Brasileira de Estudos Urbanos e Regionais, 15(2), 199-209. doi: 10.22296/2317-1529.2013v15n2p199

Rizek, C. S. (2016). Faces do lulismo: Políticas de cultura e cotidiano na periferia de São Paulo. In A. Singer \& I. Loureiro (Eds.), As contradições do lulismo: $A$ que ponto chegamos? (pp. 185-219). São Paulo, Brazil: Boitempo.

Singer, A. (2018). O lulismo em crise. Um quebra cabeça do período Dilma (2011-2016). São Paulo, Brazil: Companhia das Letras.

Streeck, W. (2018). Tempo comprado: A crise adiada do capitalismo democrático. São Paulo, Brazil: Boitempo.

Teixeira, S. F. (1992). Estado y políticas sociales en América Latina. Mexico DF, Mexico: UAM.

Teixeira, S. F. (1989). Reflexões teóricas sobre democracia e Reforma Sanitária. In S. F. Teixeira (Ed.), Reforma sanitária: Em busca de uma teoria (pp. 17-45). São Paulo, Brazil: Cortez.

Viana, A., Miranda, A., \& Silva, H. (2015). Segmentos institucionais de gestão em saúde: Descrição, tendências e cenários prospectivos. Rio de Janeiro, Brazil: Saúde Amanhã, Fundação Oswaldo Cruz.

Manuscrito recibido: 30-08-2018 Manuscrito aceptado: 01-07-2019 